\section{Seeking Senate surgery}

A radical overhaul of the Senate Commitee system is being discussed in Washington. Colin Norman reports on the implications for scientific affairs

AN entertaining display of political horsetrading, perhaps culminating in a good public scrap, is about to unfold on Capitol Hill. For the first time in more than a quarter of a century members of the US Senate are being forced, somewhat reluctantly, to take a close look at that august body's confused and inefficient but immensely important system of legislative committees. Some sweeping reforms, which could wipe out entire committees and with them the power bases of a number of influential Senators, are under discussion.

The proposed reforms were put forward a few weeks ago by a special select committee. But because public attention was diverted by the marginally more interesting spectacle of the Presidential election and a third of the Senate were preoccupied with getting themselves elected, few people took much notice. The Senate is expected to take up the proposals soon after it reconvenes in January, however, and so they are now becoming a topic of intense interest on Capitol Hill.

There are a good many political obstacles to be overcome before the proposed reforms are accepted, but if they are ever implemented they will have a substantial effect on the way the Senate handles legislation on scientific and technological matters. For a start, responsibility for energy research and development would be placed in a single committee, the jurisdiction of the present Commerce Committee would be expanded to take in most non-military science and technology programmes, and the Joint Committee on Atomic Energy, which has charted the course of the United States' nuclear policy for some 30 years, would be abolished.

Overall, the proposals would reduce the numbers of Senate committees from 31 to 15 , doing away with a variety of select, standing and joint committees, and realigning the jurisdictions of most of the remainder. The Senate's present 174 subcommittees would be cut down to about 100 , and no Senator would be able to sit on more than 8 subcommittees. In short, the proposed reforms represent some pretty radical surgery, and they would bring about the first real changes in the Senate committee system for 30 years.

Even a cursory look at the system confirms the need for a knife. The Senate's committees are so sprawling Senate floor. and their jurisdictions so confused that it is frequently difficult to tell which committee has authority over individual bills. Take energy research and development, for example. The Joint Committee is deep into one aspect of energy, so is the Interior Committee, the Public Works Committee, the Aeronautical and Space Science Committee, the Commerce Committee and the Labor and Public Welfare Committee. A couple of years ago, when a relatively non-controversial solar energy bill was passed by the House, no fewer than four Senate Committees claimed jurisdiction and it had to be approved by all of them before finally reaching the

But, though the need for reform is obvious, it is going to be a tough battle to get anything done. The problem is that Congressional committees, and to a lesser extent subcommittees, represent overlapping fiefdoms headed by powerful, and frequently elderly, chairmen whose authority has taken years to acquire. The chairmanship usually goes to the longest-serving member of the majority party on each committee, and with it comes a good deal of power to appoint committee staff, and to shape or even obstruct the passage of legislation. Thus any attempt at reform must first overcome the fact that a lot of powerful people are going to resist having their authority altered or even removed.

The House went through a mild reorganisation a couple of years ago in a move which gave the House Committee on Science and Technology a good deal more power. But those changes were only made after a couple of years' of intense negotiations and six days of shrill public debate. The Senate reforms may be equally difficult-moves are already afoot to try to shunt them aside by simply referring the whole matter to the Senate Rules Committee for further, prolonged study--but their proponents point out that conditions for change are more favourable now than at any time in the past several years. For one thing, there will be seventeen new faces in the Senate next January-a much higher turnover than usual. And for another, the chairmen of four committees threatened with the axe were either defeated or retired.

The following are the major changes proposed by the select committee in committees concerned with science and technology. It should be noted that the proposals would leave essentially untouched the real powerhouses, such as the Appropriations Committee, the
Armed Services Committee, the Finance Committee and the Judiciary Committee. Thus, some of the most powerful Senators won't be too badly affected, and appropriations for government agencies will continue to be handled by the same appropriations committees and subcommittees.

- It has been proposed that responsibility for non-military research and development policy should now fall under the present Commerce Committee, whose authority would be greatly expanded and whose name would be changed to the Committee on Commerce, Science and Transportation. The new committee would be responsible for keeping its eye on the activities of agencies such as the National Science Foundation, the Office of Science and Technology Policy, the National Aeronautics and Space Administration and the various agencies of the Departments of Commerce and Transportation. It would be the chief committee for federal research activities other than military, biomedical and energy programmes. If the proposed changes are accepted, they would cause the demise of the Aeronautical and Space Science Committee whose chairman, Frank Moss, was defeated at the polls in Utah.

- The change would also mean that Senator Kennedy would lose the authority he now holds over the National Science Foundation through his chairmanship of the NSF subcommittee of the Committee on Labor and Public Welfare. That committee would be expanded under the proposed reforms to become a Committee on Human Resources, and Kennedy is said to be negotiating to have NSF affairs consigned to it. It wouldn't be the most logical place for NSF, but at least Kennedy would be able to retain his jurisdiction.

The proposed Human Resources Committee would be responsible for, among other things, health and biomedical research, which means that Kennedy would retain much of his authority over the programmes of the National Institutes of Health.

- As for energy research and development, the select committee has proposed that the responsibilities of the present Interior Committee, headed by Senator Henry Jackson, should be expanded to include most federal energy development efforts. Renamed the Committee on Energy and Natural Resources, the new body would pick up responsibilities from the Joint Committee on Atomic Energy and a number of other committtees. The proposal would put the knife into the back of the Joint Committee, the once-powerful unit which has shaped nuclear policy 
since the second World War.

The Joint Committee is in trouble for other reasons, too. Next month, when Democratic members of the House meet to discuss the political agenda there, two nuclear critics, Clarence Long of Maryland and Jonathan Bingham of New York, will propose that the committee be scrapped and that some of its functions be transferred to the House Science and Technology Committee, among others. Thus, the Joint Committee is under combined attack in both the House and the Senate, and its chances of surviving are generally considered to be less than even. One point going against the committee is that five of its nine members, including the chairman, Senator John Pastore of Rhode Island, either retire at the end of this year or were defeated at the polls. Moreover, two of the most powerful members of the Joint Committee, Senator Jackson and Representative Mike McCormack, would stand to inherit some of its authority in their own committees, so they probably wouldn't be too sorry to see the Joint Committee disappear. It should be noted that the Joint Committee has been consistently pro-nuclear, and its demise would be welcomed by anti-nuclear critics.

- Another major Senate change proposed by the select committee is the creation of a new committee on Environment and Public Works, founded mostly on the present Public Works Committee headed by Senator Jennings Randolph. It would be responsible for environmental programmes together with nuclear regulation, which would mean that responsibilities for developing and regulating nuclear power would be divided between separate committees.

The proposed reforms are expected to be one of the first items of business when the Senate reconvenes early in January, but negotiations are already under way behind the scenes, as Senators who stand to lose some of their jurisdiction are striving to hang on to their authority.

It is quite possible that the opposition will be too strong and that the proposals will be quietly killed off or severely watered down by consigning them to the Rules Committee for further study. But at least the proponents of the reforms are preparing to put up a spirited fight. Senator Adlai Stevenson, the chairman of the select committee, is said to be threatening to introduce a resolution blocking the appointment of new senators to committees and the appointment of new committee chairmen if his proposals are simply shunted aside. Such a resolution could tie up the business of the Senate for a long time if it were approved. A more likely development is that differences will be settled by behind-the-scenes negotiations in the next few weeks, and a compromise reform plan will be worked out in conjunction with the Rules Committee.

\section{Genetic manipulation: enter the environmentalists}

LAWYERS for two environmental organisations have filed a formal petition with the Department of Health, Education and Welfare (HEW) requesting extensive public hearings and the development of legally binding regulations to control all recombinant DNA experiments in the United States. It is the first time that environmentalist groups have formally entered the swirling dispute over the risks and benefits associated with recombinant DNA, and the petition is probably only the opening shot in what could develop into a lengthy legal fight.

Filed by the Environmental Defense Fund and the Natural Resources Defense Council, the petition has been endorsed by Robert L. Sinsheimer, chairman of the Division of Biology at California Institute of Technology. Sinsheimer, a leading critic of recently-issued safety guidelines governing recombinant DNA research supported by the National Institutes of Health (NIH), sent a letter to HEW along with the petition.

The petition requests two actions by HEW. First, public hearings should be held to allow interested parties to state their case and to have their views taken into account; and then HEW should develop binding regulations to control all recombinant DNA experiments in the United States. In the meantime, the petition asks HEW to extend the voluntary NIH guidelines to cover experiments supported by other agencies and by non-government bodies.

The petition is clearly motivated by the belief that the NIH guidelines are inadequate to control the potential hazards associated with recombinant DNA research. It states that the guidelines "are the product of the deliberations of scientists who are now conducting recombinant DNA research", and argues that "little discussion was devoted to whether or not these experiments ought to be performed at all, even though the question was raised both by concerned laymen and by prominent scientists".

The petition also points out that the chief drawback in the guidelines is that they formally apply only to research supported by NIH, leaving industrial research essentially unregulated. Moreover, there is no requirement for federal monitoring to ensure that the guidelines are being followed. Those drawbacks are also bothering some state and local officials, in New York State for example.

The petition will probably be turned down on the grounds that HEW lacks authority to tell other agencies or private industry what to do, but the environmental groups are likely to press their case either in the courts or on Capitol Hill. Senator Edward Kennedy has already said that he may consider introducing legislation to make the NIH guidelines binding on everybody who wants to conduct recombinant DNA studies.

Meanwhile, an inter-agency task force has been established in Washington to discuss ways in which the NIH guidelines can be extended to other federal agencies. According to one official concerned with the task force, it will also discuss the possibility of establishing a monitoring procedure to ensure that the guidelines are followed, and it will also look into what industry is doing and whether the federal government could (or should) regulate industrial recombinant DNA experiments. One possible outcome of the task force's deliberations is that the NIH guidelines may be made into legally binding regulations covering all agencies and industry as well. If so, that would accomplish some of the petition's demands.

The task force is headed by Dr Fredrickson, and consists of representatives of other federal agencies. It meets in private since it does not fall under the terms of the advisory committee act, and it is expected to come up with some recommendations by mid-January.

If it does recommend the adoption of legally binding regulations and a monitoring procedure, a key question would be which agency should take responsibility for enforcing them. NIH officials are anxious not to be placed in the position of both supporting and regulating the research, and the task may therefore fall to a regulatory agency such as the Occupational Safety and Health Administration. 